\title{
Chapter 18 \\ Movimiento Ventana: An Alternative \\ Proposal to Mental Health in Nicaragua
}

\author{
Andrea Deleo, Roberta Romero, and Enmanuelle A. Zelaya
}

\subsection{Introduction}

Mental health is recognized as a fundamental part of health and is considered a basic global priority for the overall well-being of individuals, societies, and countries (WHO 2013), and is identified as one of the targets in the UN Sustainable Development Goals (SDGs) from 2015 to 2030. Despite this, resources and funding for this area of health represent a budget of less than $1 \%$ in most countries, including Nicaragua. In addition, Nicaragua does not have policy or legislation on the subject (PAHO 2013), and most of the services are centralized in the Psychosocial Care Teaching Hospital "José Dolores Fletes Valles." These factors leave an overwhelming treatment gap and help maintain an asylum model of treatment that contradicts the worldwide resolutions to develop programs for community-based care (PAHO 2013).

Nicaragua is one of the poorest countries in the Western Hemisphere and its population is prone to developing psychosocial problems due to multiple traumatic events that have occurred in its history (wars and armed revolutions, corruption, poverty, natural disasters, etc.). This results in a psychologically vulnerable population and is combined with risk factors such as substance abuse, commercial and/or sexual exploitation, high rates of violence, high rates of femicide, teenage pregnancy, illiteracy, and severe mental disorders.

At the moment, Nicaragua is immersed in a socio-political and human rights crisis that began in April 2018 with a series of social protests that were violently repressed by the authorities and pro-government armed groups. The evidence shows that the overall response of the government to these protests failed to meet

Translation by Audrey Sharp

\footnotetext{
A. Deleo $(\bowtie) \cdot$ R. Romero $\cdot$ E. A. Zelaya

Movimiento Ventana, Managua, Nicaragua

e-mail: movimiento.ventana@gmail.com 
applicable standards of the management of assemblies, in violation of international human rights law. Other human rights violations documented include disproportionate use of force by the police that sometimes resulted in extrajudicial killings; enforced disappearances; obstructions to access to medical care; widespread arbitrary or illegal detentions; prevalent ill-treatment and instances of torture and sexual violence in detention centers; and violations of freedom of peaceful assembly and expression, including the criminalization of social leaders, human rights defenders, journalists, and protesters considered critical of the government (United Nations Human Rights 2018).

This crisis has implied a setback in terms of democracy, destabilizing the territory and leaving by the end of 2018 more than 300 deaths, 2000 persons injured, and approximately 740 political prisoners (Amnesty International 2018; United Nations Human Rights 2019). The situation has affected all social spheres, forcing thousands to migrate or live in exile, polarizing Nicaraguan society, and extending poverty levels (FUNIDES 2018). This has forced us to suspend activities at Movimiento Ventana due to levels of insecurity in the country and repression of any form of organization outside the government. When the crisis comes to an end, we will have the challenge as a country to re-establish democracy and respect for human rights, and also the opportunity to heal the psychosocial traumas we have carried through our history and build a healthier society. As a social movement, we hope to be part of these processes to heal old and new traumas.

\subsection{Movimiento Ventana and its Beginnings}

Movimiento Ventana traces its beginnings back to 2011, when four students in their last year of high school were developing a monographic project relating to schizophrenia in the Psychosocial Hospital in Managua, Nicaragua. Entering the hospital meant being confronted by a reality hidden behind the walls of the institution; it inevitably gave a very disconcerting first impression to experience firsthand the facility's scarcities, enclosed rooms, limited access to basic health resources, and the use of drugs as the primary means to inhibit undesirable behavior. This striking reality motivated the students to organize a way to improve the conditions in which people with mental disorders were living. This gave way to the first activity in the Psychosocial Hospital at the end of November 2011, where users, students, and a few volunteers used art-based elements to create a common space.

Then, in 2012, the students began to organize structured visits that facilitated Art Therapy techniques as a means to guide interactions in the activities. Since then, the visits have taken place every fifteen days, or two Saturdays a month. Over time, other techniques such as laughter therapy and psychodrama have been used, and beginning in 2016, we started to implement Biodanza as an additional work modality. 


\subsubsection{Why Movimiento Ventana?}

The name Movimiento Ventana (see Fig. 18.1 for the its logo) is in honor of Alfonso Cortés (1893-1969). Cortés, a famous Nicaraguan poet that belonged to the postmodernist movement, is considered to be one of the three greats, after Rubén Darío. Cortés wrote Ventana (Window) and other literary works in a psychotic state, and although he was recognized for his art, he spent many years of his life locked away in a room in his home and later on in the same psychiatric hospital that we visit today. Because of his mental disorder, Cortés was a victim to the same stigma of society that persists today. The poetic and symbolic background of this poet and his work made him the perfect frame for what we wanted to accomplish with this movement: to open a window for the people living in this hospital.

Movimiento Ventana's activities have improved over the years, learning empirically through the practice of merging the activities with a complementary theoretical knowledge. It is in that way that we've moved from an assistive perspective (based merely on the intention to help) to a perspective geared toward recovering and restitution of rights.

From its beginning until now, the movement has functioned in a completely selfrun manner - that is to say, without relying on any permanent financial support from an organization or institution. Its survival has been based on the symbolic contribution of volunteers and donors coming from within our own networks. Today, Movimiento Ventana relies on a core team of volunteers that manage each visit to the hospital. The team is made up of twelve people with diverse degrees and is divided into five work groups-finances, communication, volunteer work, training, and human development-with each group responsible for different tasks. The volunteers dedicate their time, knowledge, and abilities to the creation and

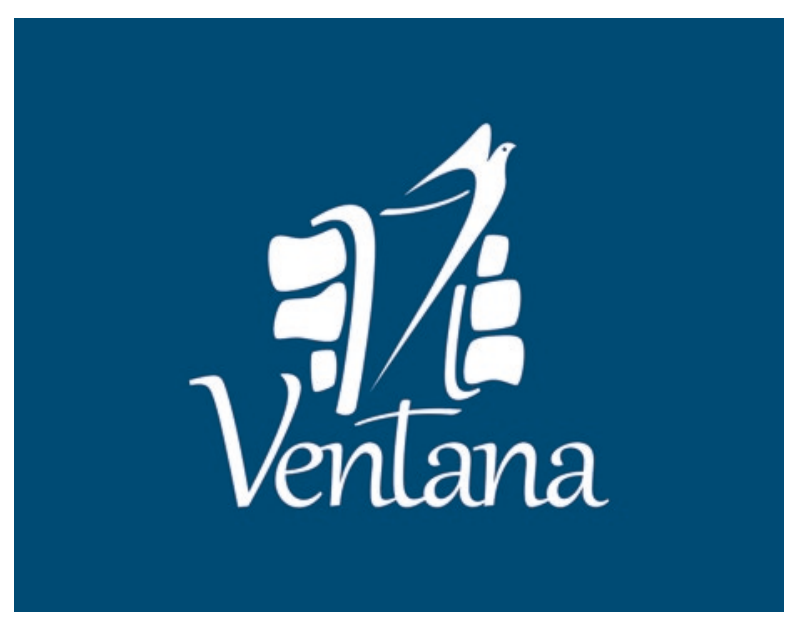

Fig. 18.1 Movimiento Ventana logo 


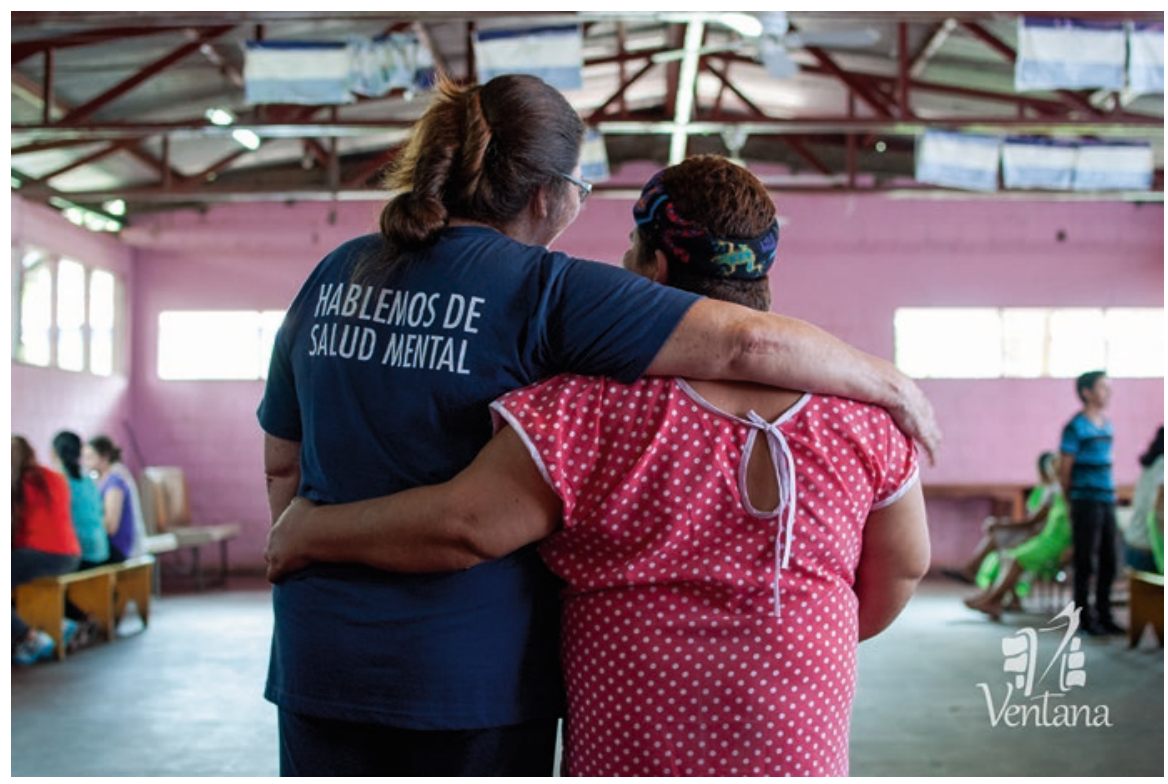

Fig. 18.7 "Let's talk about mental health" Movimiento Ventana motto. (Photo credit: Cristiana Castellón)

development of Movimiento Ventana. In this way, we stand out not just as an organized movement, but as a movement built in a collective.

Currently, Movimiento Ventana is defined as a social movement that works to promote mental health and reduce stigma against people living with mental disorders. This is achieved through formative mental health spaces placed in various spots throughout the capital (high schools, universities, other non-profits, etc.) and through social volunteering at the Psychosocial Hospital where alternative therapeutic activities (Biodanza and Art Therapy) are implemented with users. Volunteering is kept open for the various activities in an effort to address the topic of mental health with the general public without any fear or stigma, so that we can begin to talk about mental health as a part of the human experience and recognize that it is a part of ourselves that we should look after as much as we do our physical health. This is why our main motto at Movimiento Ventana is: "Let's talk about mental health" (Fig. 18.7.).

\subsection{Conceptual Framework}

Movimiento Ventana's work is developed around a focus on mental health promotion, human rights, and gender. Using this approach, we understand people as biopsycho-social beings and recognize that mental health is a question of welfare that 
goes well beyond the absence of illnesses (WHO 2013). As well, we revisit how health and illness are intimately related with the intersectionality between social constructs such as sex, gender, race, ethnicity, age, religion, and economic status (Bauer 2014). Furthermore, we recognize that within this work, there is a convergence of certain power dynamics and varying social and scientific understandings of what it means to be crazy (Foucault 1990; Goffman 1970). This marked stigma that exists in the population - and within the very same mental health professionals helps to form a pertinent barrier to addressing the social integration of people living with mental illnesses (Arnaiz and Uriarte 2006). Thus, we are looking for new ways to tackle mental disorders, moving away from the closed-minded, institutional model built around illness and instead moving toward a community-comprehensive, open-minded, and complex model built around fortitude, capacity, and rights recovery (Rodríguez et al. 2009).

For this approach, we use the personal recovery model as a theoretical-conceptual basis, a relatively new term based on the subjective processes of self-improvement in spite of an illness (Rebolleda and Florit 2010). The World Health Organization set forth this concept of personal recovery, understood from the perspective of a person living with mental illness, in their Mental Health Plan 2013-2020:

Gaining and retaining hope, understanding of one's abilities and disabilities, engagement in an active life, personal autonomy, social identity, meaning and purpose in life and a positive sense of self. Recovery is not synonymous with cure. Recovery refers to both internal conditions experienced by persons who describe themselves as being in recovery-hope, healing, empowerment and connection-and external conditions that facilitate recovery-implementation of human rights, a positive culture of healing, and recovery-oriented services (WHO 2013, p. 43).

According to this model, the term "public health services user" replaces the term "patients" (Rebolleda and Florit 2010), with the understanding that the use of the word "patient" denotes a position of passive, dependent, and stigmatizing inequality. Instead, the word "user" refers to an individual in search of professional support, with strengths and weaknesses, with rights, and with a capacity to form an opinion on their own active journey toward recovery.

Lastly, we are reclaiming alternative models of mental health that leverage art and expression as a means to strengthen well-being and as a therapeutic tool to work and develop areas where traditional therapies are limiting. As mentioned in Chap. 1 in this volume, art can be a tool to address complex health promotion issues, and also act as a bridge connecting people to one another in their humanity.

The British Association of Art Therapists (1969) defines Art Therapy as a form of psychotherapy that uses art media as its primary mode of expression and communication. In the same sense, Menéndez and Olmo (2010) define Art Therapy as a psychotherapeutic modality that utilizes artistic language and the creative process to express personal contexts and life experiences, create meaning, and work on psychological conflicts. Research on the use of Art Therapy with people living with mental disorders highlights the benefits achieved from this technique. Vallejo (2011), Menéndez and Olmo (2010), and Ceballo et al. (2012) found, at a psychological level, improved levels of self-esteem, self-affirmation, and self-awareness; 
recognition and expression of emotions; and a reduction in psychiatric symptoms with an improved orientation toward reality. At a group level, they found positive therapeutic results in the development of social interaction, social abilities, altruistic behavior, and companionship.

On the other hand, the epistemological origin and practice of Biodanza (which literally means "dance of life") dates back to 1965; its founder, Rolando Toro, developed and incorporated this technique in a psychiatric hospital in Chile, using dance as a form of therapy to help "humanize psychiatry" (Toro and Terrén 2011). From that point on, he discovered the influence that music, body movement, and exercise has on people, and his techniques have continued to spread across the globe. After nearly half a century since its creation, Biodanza is defined as an affective system of integration, organic renovation, and relearning of the original functions of life (Toro and Terrén 2011). Based on experiences prompted by dance, music, singing, and group settings, it has constituted itself as a complementary approach with its own paradigm.

In Biodanza, there exists five areas of growth, called "lines of experience," which summarize the five universal functions common to everybody: vitality, sexuality, creativity, affectivity, and transcendence. The results found in Biodanza-related research reflect that people, after participating in Biodanza sessions, showed signs of being more motivated, relaxed, and supported while demonstrating a better grasp of their feelings, an improved expression of basic emotions, a lowering of their defenses, reinforcement of positive emotions, increased creativity and spontaneity, better posture, higher rates of visual contact, and development in their social abilities (Castro and Rossi 1996; Granada and Sáez 2005).

Art Therapy and Biodanza, due to its methodological essence, provides elements necessary to creating a safe, therapeutic environment and an equal, homogenous understanding. These elements foster the user's empowerment, and its application at a group level provides for more dynamic methods and a development in diverse areas such as affectivity, self-esteem, self-understanding, expression, creativity, psychomotricity, social abilities, verbal communication abilities, and behavioral control.

\subsection{A Look into Movimiento Ventana's Activities}

The social volunteer activities within the Psychosocial Hospital are Movimiento Ventana's primary mission, as they allow us to influence both the users and the general population that attends. It is because of this that a major part of our efforts revolves around these activities, and the ways in which we develop such activities have adapted and improved over time. 


\subsubsection{Activity Coordination}

To start, the core team meets to plan the activities and design the central therapy that will take place at each visit, be it Art Therapy, Biodanza, or an alternative recreational activity that might coincide with a special celebration (including the Day of Love and Friendship, Mother's Day, International Mental Health Day, etc.). Weeks before each visit, all of the logistical details are prepared in order to implement the activities, such as putting out a call-to-action on social media, coordinating transportation, and compiling recreational materials and snacks. For this, Movimiento Ventana works with a methodology called support networks, where a few organizations and individuals provide materials for the activities either on a permanent or sporadic basis. Our primary support network has been Saint Teresa's Academy (an institution that has helped us since the beginning), who provides for the transportation of volunteers for each visit. We also depend on the collaboration of a few young volunteers and entrepreneurs who provide food for each visit. One of the best examples of this method has been working with approximately 20 fruit vendors at the Israel Lewites Market. Each vendor donates as much fruit as they can and together create a big fruit salad to be shared at the activity. This provides a crucial nutritional supplement that the hospital users would typically go without, while at the same time creating a space to talk about the importance of mental health among the market workers.

The other main preparation point mentioned earlier is the call-to-action, which mostly happens through a Facebook event and by word-of-mouth, but also is spurred by visiting university classrooms or speaking to specific groups of people, such as psychology students.

\subsubsection{Activity Execution}

The visits take place for four to five hours throughout the morning. Each one begins with a gathering at a central point in the capital, where volunteers and the core team are picked up and brought to the Psychosocial Hospital via private transportation. The volunteers that participate are almost entirely young people who live in the capital and are predominantly between the ages of 18 and 25 years old; there is on occasion a more experienced professional that joins.

The activities typically begin by working with the volunteers to lower their defenses, reduce anxiety, and create a trusting environment. In this space, we also provide orientation, clear up any doubts, and communicate hospital rules (such as not taking any photos or videos), while also striving to foster a space of openness, trust, respect, and safety. 


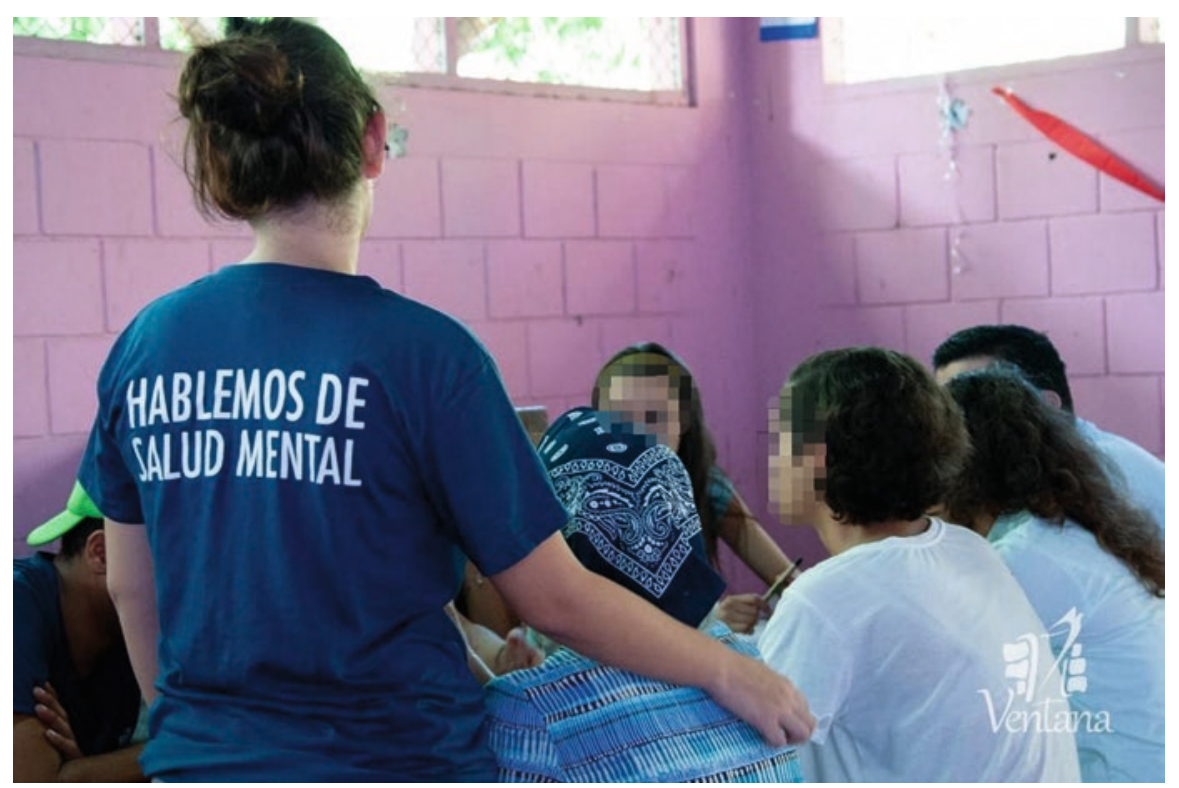

Fig. 18.2 Educational segment at the beginning of the activities. (Photo credit: Cristiana Castellón)

Next, an educational activity takes place where volunteers dialogue about a theme relating to mental health (Fig. 18.2). This educational segment is very important to the visit because it makes our volunteers more aware by sharing important information in a simple and practical way. Some of the questions tackled include: What are the myths and realities surrounding mental disorders? What is stigma? Other basic topics relating to personal experience with mental health are explored, such as: What is self-esteem? What is resilience? What factors can affect your mental well-being?

After preparing the volunteers, we continue on with the main activity for the day. The users start to arrive and we are met immediately with joy, especially from those who have attended an activity before. Then, depending on the day, the session of Art Therapy or Biodanza begins. There are typically around 30 users, with an equal mixture of men and woman, and the ideal scenario is that there is at least one volunteer for every two users; this provides for the best interaction and allows volunteers to support the users throughout the session. After the main activity finishes, the volunteers, users, and nursing staff share a snack together. It is an emotional closing space between the volunteers and the users. Afterward, the users say goodbye to the group and return to their pavilions.

The visit culminates in a segment of feedback and empathetic listening with the volunteers, led by the core team. This is the key moment for them to share about their experience, navigate certain lessons, and absorb what they've learned that day. 


\subsubsection{Art Therapy and Biodanza}

As both Art Therapy and Biodanza are central elements of each visit, art and creativity are always at the center of each session; however, each element has its own distinctive features.

In the case of Art Therapy (Fig. 18.3), the sessions can last as long as an hour or an hour and a half and are not implemented from a specialized clinical psychotherapy approach, but rather are employed in a group format under a free and nondirective methodology. Although the process is completely therapeutic, it does not possess the rigorousness of a theoretical, methodological, and practical structure that more formal sessions within a psychotherapy process would have. The focus instead is geared toward stimulating creativity and integrability while at the same time promoting self-expression, a relationship with both the internal and the external, an emotional connection, and empowerment. To facilitate this, different artistic materials are provided, and the volunteers and users collaborate as a group to create projects. These activities leave a lot of space for verbal interaction and other spontaneous activities such as dancing and singing.

On the other hand, Biodanza (Fig. 18.4) relies on a specialized facilitator that guides the sessions to develop the five lines of experience suggested by the technique. The sessions last between 45 minutes and an hour, in which the facilitator reproduces previously selected music specifically for the line of experience being worked on that day, along with the related movements and exercises. On many occasions, the Biodanza sessions turn into accompaniment sessions, where the volunteers model the facilitator's instructions to the users, accompany them, and set the pace. This is due to the fact that the users often possess rigid psychomotricity and a

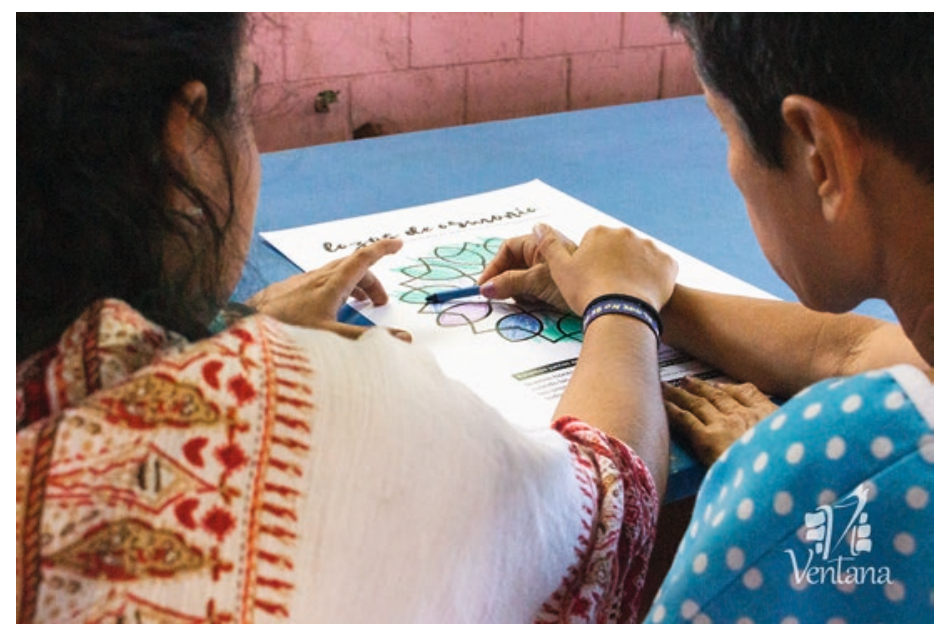

Fig. 18.3 Development of an Art Therapy activity in the Psychosocial Hospital. (Photo credit: América Solórzano) 


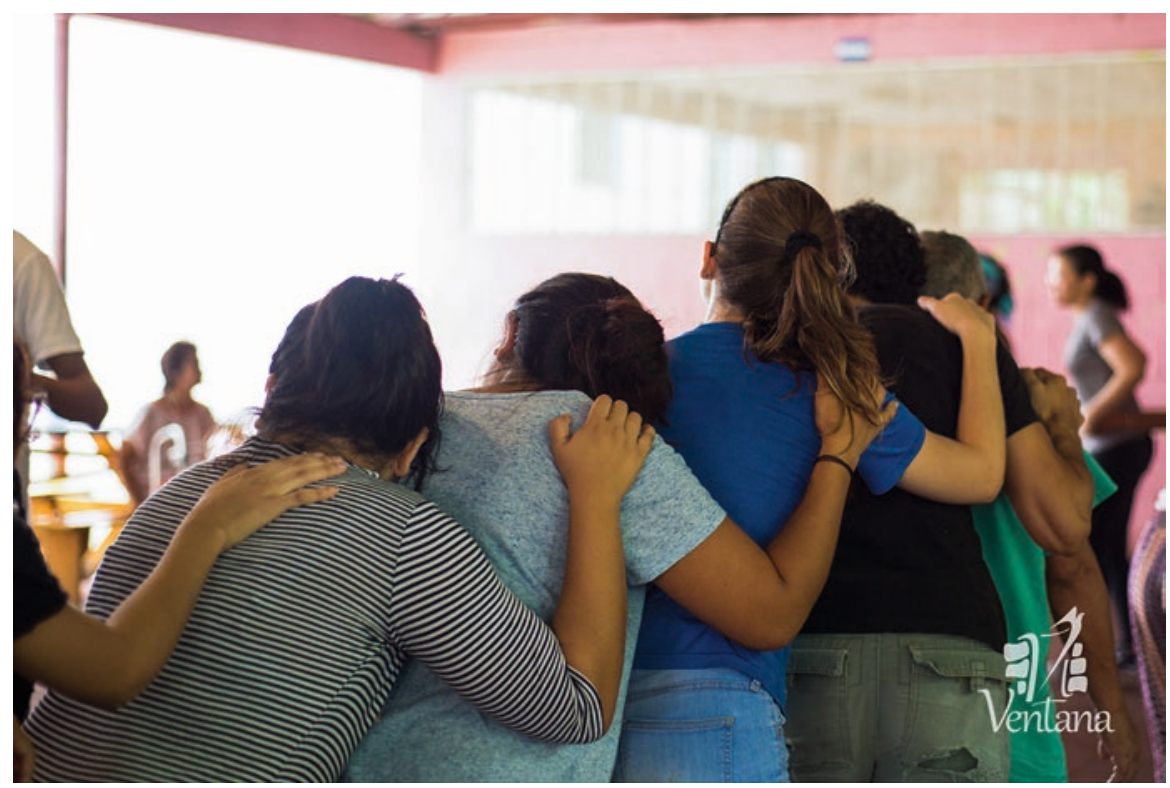

Fig. 18.4 Use of movement and body expression in Biodanza activity. (Photo credit: Gina Solórzano)

limited attention span, and this is why the volunteers' participation is fundamental to the success of the conciliatory experience.

Both techniques, by nature of their practice, create an opportunity to create connections, laugh, hug, and speak, and-in their applied forms - can facilitate established trust, human contact, and a mutual agreement. Additionally, the visits help to build a perception of people facing mental health challenges as individuals with qualities, strengths, and deficiencies like anyone else, where their mental disorder is more a variable than a condition.

Some of the results we gathered from the activities' work was found from exploratory research done by Deleo and Gutiérrez (2016). The authors identified the perceptions the participants have of Movimiento Ventana's activities through five in-depth interviews of hospital users, two focal groups within Movimiento Ventana's volunteers, and observations from a series of Art Therapy and Biodanza activities within the hospital. One major contribution to this research was centered on the perception of the users, reclaiming a point of view typically forgotten by science and rescuing the protagonist role of people with mental disorders during the recovery process. Among its biggest findings is the emphasis on how the activities are seen as a space for expressing oneself, getting to know oneself, sharing, enjoying, and using Art Therapy and Biodanza as a means to group interaction. For the users, these aspects were highlighted as principal within the activities, yet they provided little therapeutic attribution to the techniques. Conversely, for the volunteers, the 
activities were related to personal growth and in contrast to the users, they expressed consciousness of the therapeutic contribution of the activities.

Despite the users not directly recognizing the activities as therapy, within discourse, the authors found aspects that alluded to a state of improved well-being as a result of their participation in the activities. Among these, they found changes in their affective experience, an increase in their recognition of emotions, the development of skills for the adequate management of behaviors, greater control of their actions, and an increase in the initiative to participate in activities. They also found changes in social relations, considering that the volunteer work was postulated as a support network for users. Specifically, in each technique, they found that Art Therapy favors the development of verbal expression and an evolution in language, while Biodanza facilitates the significant improvement of body movements and greater fluidity, as well as an increase in contact capacity and reciprocity.

On the other hand, Tchaikovsky (2017) systemized Movimiento Ventana's experiences between 2011 and 2016. For this, she applied in-depth interviews from different actors: four hospital users, two members of the nursing staff, the general director of the Psychosocial Hospital, and the Biodanza specialist that facilitates sessions. She also applied a focal group with the core team of Movimiento Ventana. In her study, Tchaikovsky highlights Movimiento Ventana's evolution throughout the years, specifically noting its departure from an assistive approach and its move toward a comprehensive vision that promotes and enables the empowerment of users. The author emphasizes as a key factor the volunteers' perception of the users, which transformed over time from "patients" to "friends," allowing for affective reciprocity and engendering a greater commitment and motivation to the cause.

Finally, she finds that Movimiento Ventana's activities provide a solution to the negative symptoms of the illness, having a direct and positive influence on affective weakness, emotional distance, apathy, lack of initiative, and more. Many of these are symptoms that are resistant to pharmacological treatment and, with increasing intensity, can determine the longevity of the disorder.

\subsection{The Volunteers' Experience}

For the volunteers, the visits provide a unique space for awareness, learning, dialogue, and a reflection on mental health and the reality of what it's like to live with a mental disorder. By participating and interacting with the users (Fig. 18.5), the volunteers have the opportunity to confront and question these ideas, prejudices, and stigmas that society has taught them about mental illness.

Volunteers experience varied emotions on these visits; some volunteers connect with the users' energy, enthusiasm, and willingness to share, while others better understand the environment and social limitations being placed on the users. Others also ask themselves, "How is it possible that nobody is talking about this?" Or they simply feel guilty for having long thought that people with mental disorders were violent or crazy, for example. 


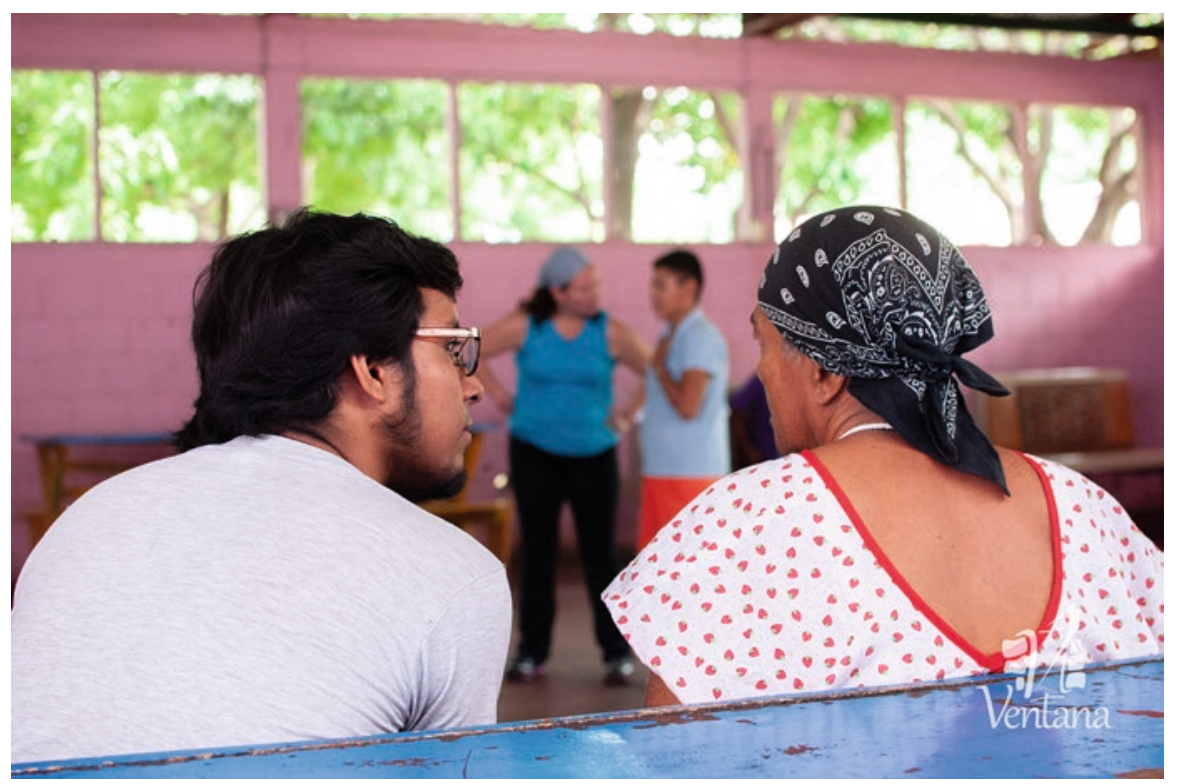

Fig. 18.5 Conversation between volunteer and user in an activity. (Photo credit: Cristiana Castellón)

The volunteers' experience with the users is crucial for diminishing negative assessments of them; it takes away the perception that users are dangerous or unpredictable, which the stereotype on mental illness often implies, and thus mitigates the insecurity and fear that might stand in the way of them meeting or getting to know someone living with a mental disorder (Arriba-Rossetto et al. 2008). In this way, as stated in Chap. 21 in this volume, arts-based activities allow to deepen connections with others by creating a shared experience of new knowledge or by increasing empathy for others' lived experiences.

Likewise, we look to create a natural and comfortable space, where the volunteers can identify with the personal experiences of others and feel safe sharing about their own mental health without feeling judged and can trust, count on the support of others and can realize the importance of mental health (Fig. 18.6).

\subsection{Successes and Challenges}

Among the successes achieved at Ventana is the completion of nearly 7 years of work and being one of the first groups to focus exclusively on the topic of mental health in Nicaragua. Through these years, we have been able to address the topic of mental health with more than 1000 volunteers and carry out approximately 112 hospital visits to the Psychosocial Hospital. We have developed a strategy to reduce 


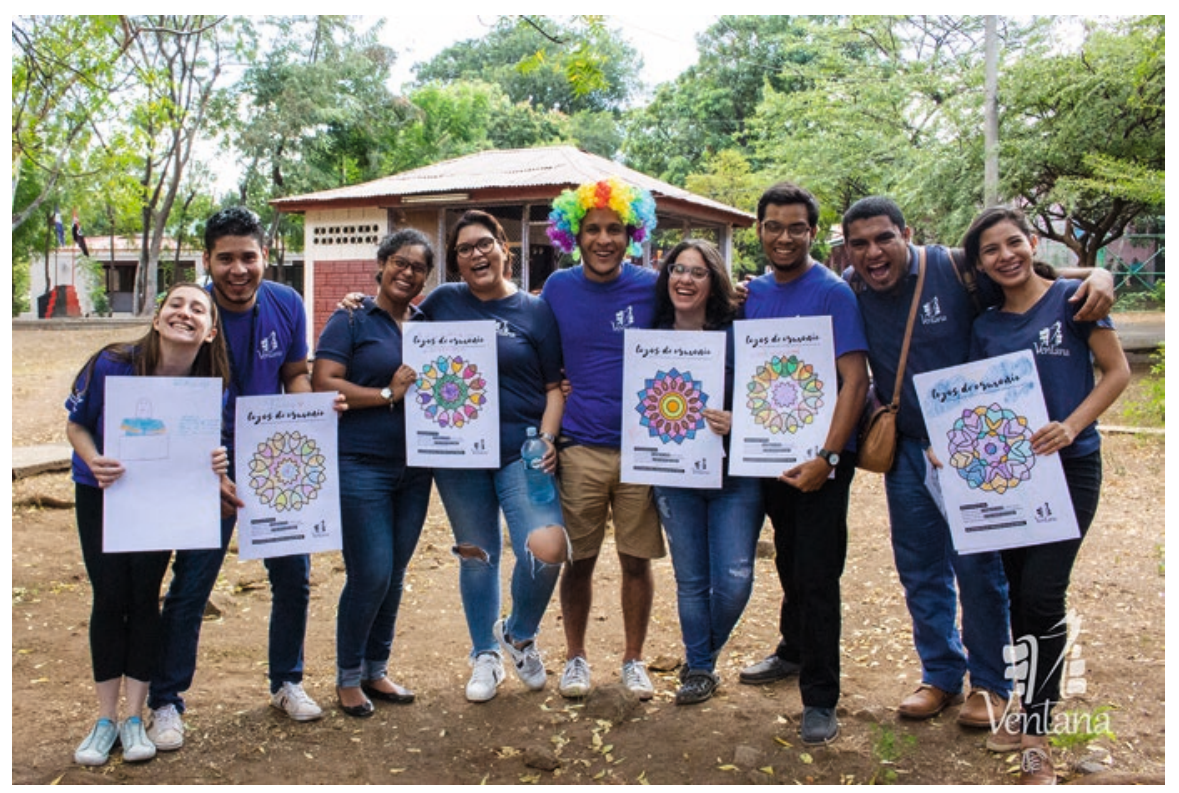

Fig. 18.6 Group photo at the end of an Art Therapy activity. (Photo credit: América Solórzano)

mental health stigma that combines first-hand experience with simple and practical information, components that have been identified as key to promoting social change (Arnaiz and Uriarte 2006). And we have successfully implemented artbased activities such as Art Therapy and Biodanza in a group and non-directive format that results in an effective and cost-efficient accompaniment to the recovery and promotion of mental health with users.

Among the challenges faced have been the lack of theoretical knowledge of mental health matters on part of some team members, not being legally registered as a social organization or NGO, and the scarce systemization and record-keeping of successful activities over the years. These facets limit measuring achievements, the development of new activities as an organized movement, and the possibility of obtaining long-term financing.

In addition, another challenge has been coexisting within a hospital that maintains a model of asylum-prison care and working with institutionalized users that have lost most of their community roles and connections, present severe motor and cognitive limitations, and are treated almost exclusively with high levels of psychiatric drugs. These have proven to be large barriers to Ventana's stated goals of recovery and promotion of mental health, while at the same time threaten users' human rights.

As staff and professionals, we also continue to battle our own stigmas and question our roles of power within this system. It is a constant challenge not to fall into 
discriminatory, exclusionary, relief, or caretaking practices when working with mental health users.

Another important point is that, as we mentioned at the beginning of the chapter, in April 2018 we have been forced to suspend all activities due to a high level of government repression. The fact that the Psychosocial Hospital is a public psychiatric institution that depends on government support and requests has meant that our volunteer work has been interrupted indefinitely. This has created an uncertain future for the movement and poses a great challenge, but also an opportunity to rethink new strategies for the mental health field in Nicaragua.

Our work over the years has taught us the importance of the systemization of work and ongoing training for the project team. Equally, it has highlighted the possibilities that the use of art can open up in creating new forms of treatment and community integration that are removed from the asylum model, as well as the need to continue to encourage the empowerment and participation of people living with mental disorders and health care practices that are in line with these principles. As is the claim of people living with mental health challenges around the globe, "Nothing about us without us!"

\subsection{Conclusion}

Around the world, there are a number of examples of social organizations working to improve mental health care, enhance living conditions, and reduce stigma toward people with mental disorders. Many of these, including Movimiento Ventana, use art in its diverse modalities (theater, music, dance, plastic arts, writing, radio production, etc.) both for its therapeutic benefits and for the opportunities it provides for social participation and group empowerment. Examples of such artistic approaches include the "Radio La Colifata," "Radio Vilardevoz," "Abracadabra Creatividad," and the "Frente de Artistas del Borda," (Mad in América Hispanohablante 2017) to name just a few. These experiences in the field of creativity and mental health show how collectivity and the recognition of rights can generate a social and political impact in the creation of laws and public policies of countries, and can open pathways for freedom, autonomy, and decision-making in the processes of recovery and in the overall lives of people living with mental disorders.

In this way, art now becomes a tool and a bridge for transformation at the individual, community, and social levels that attempts to traverse the real and symbolic walls of the insane asylum, or "manicomio," generating links toward the community and reverting the codifying effects of the insane asylum practices-thus enabling the users to position themselves as active subjects of their decisions and of the transformation of their own reality by the path of artistic experience (Bang 2016). Similarly, its practical implementation enables generating the opposite of insane asylum practices; that is to say, it allows for going from the loss of subjectivity, 
stigmatization, and confinement of people to the creation and re-creation of subjective productions within group-based and communal bonds (Gutiérrez et al. 2018).

The use of art through the alternatives therapies of Art Therapy and Biodanza has allowed us to have a direct and positive impact on the users, at both individual and social levels, in areas such as a growth in their recognition of emotions, development of verbal expression, greater control of their actions, improvement and greater fluidity of body movements, an increase in capacity of contact and reciprocity, and a decrease in the negative symptoms of their illness. As well, the use of art techniques fosters social participation and a more active role of users in the activities (Deleo \& Gutiérrez 2016; Tchaikovsky 2017). In this way, Art Therapy and Biodanza have proven to be effective techniques when working with people living with mental disorders and show that, when applied in a group format, they are a more cost-effective and comprehensive development approach (Menéndez and Olmo 2010). Parallel to this, the space in the activities allows us to work with the community to transform the social image of what is understood by "madness" and "being crazy," promote the importance of mental health, and contribute to building a society more inclusive of psychosocial diversity.

Beyond the specific techniques, human connections, mental health service users' empowerment and the creation of more horizontal spaces are fundamental and shed light on a possible path toward recovery. We recognize that when working with users facing mental health challenges, it is important to not only take into account the techniques that are applied but also to consider the way in which this specific population is approached (Deleo and Gutiérrez 2016), namely one of respect and recognition for human rights and fundamental freedoms (Fig. 18.7).

\section{References}

Amnesty International. (2018). Instilling terror: from lethal force to persecution in Nicaragua. https://www.amnesty.org/en/documents/amr43/9213/2018/en/. Accessed 3 Dec 2018.

Arnaiz, A., \& Uriarte, J. J. (2006). Estigma y enfermedad mental. Norte de salud mental. http:// documentacion.aen.es/pdf/revista-norte/volumen-vi/revista-26/049-estigma-y-enfermedadmental.pdf. Accessed 20 Oct 2018.

Arriba-Rossetto, A., Seoane-Pesqueira, G., Senra-Rivera, C. (2008). Papel de la experiencia en la aceptación vs. rechazo del paciente con esquizofrenia. Revista Latinoamericana de Psicología. https://www.researchgate.net/publication/26576290_Papel_de_la_experiencia_en_la_aceptacion_vs_rechazo_del_paciente_con_esquizofrenia. Accessed 10 Oct 2018.

Bang, C. (2016). Creatividad y salud mental comunitaria: tejiendo redes desde la participación y la creación colectiva. Argentina: Buenos Aires.

Bauer, G. (2014). Incorporating intersectionality theory into population health research methodology: Challenges and the potential to advance health equity. Social, Science \& Medicine. https://www.researchgate.net/publication/261407967_Incorporating_intersectionality_theory_ into_population_health_research_methodology_Challenges_and_the_potential_to_advance_ health_equity. Accessed 18 Oct 2018.

British Association of Art Therapists. (1969). What is art therapy? The BAAT Register. https:// www.baat.org/About-Art-Therapy. Accessed 10 Oct 2018. 
Castro, M., \& Rossi, M. (1996). Influencia de la biodanza en el proceso terapéutico. Dissertation: University of San Carlos, Guatemala.

Ceballo, Y., Vasconcelos, J., Ferreira, A. (2012). Efectos de un programa de arteterapia sobre la sintomatología clínica de pacientes con esquizofrenia. Dissertation: Central University of Venezuela.

Deleo, A., \& Gutiérrez, Y. (2016). Arteterapia y biodanza en el Hospital Psicosocial. Un análisis desde las y los participantes. Dissertation: Universidad Centroamericana UCA. http://repositorio.uca.edu.ni/4836/. Accessed 20 Sep 2018.

Foucault, M. (1990). Technologies of the self. Barcelona: Paidós Ibérica.

Fundación Nicaragüense para el desarrollo económico y social. (2018). Economic impact of social conflicts in Nicaragua 2018. FUNIDES register. http://funides.com/noticias/436-economicimpact-of-social-conflicts-in-nicaragua-2/. Accessed 10 Oct 2018.

Goffman, E. (1970). Stigma: Notes on the management of spoiled identity. New York: Simon \& Schuster. https://sociologiaycultura.files.wordpress.com/2014/02/goffman-estigma.pdf. Accessed 10 Oct 2018.

Granda, A., \& Sáez, R. (2005). Efectos de la biodanza en las habilidades sociales básicas de los pacientes esquizofrénicos. Revista de Psicología, 7, 25-31.

Gutiérrez, L., Scocozza, S., Garavetti, R., Gonzalez, A., Oliveto, C. D. (2018). Arte y salud mental. Recomendaciones para la red integrada de salud mental con base en la comunidad. Irección Nacional de Salud Mental y Adicciones. http://www.msal.gob.ar/images/stories/bes/ graficos/0000001358cnt-2018-10_arte-y-salud-mental.pdf. Accessed 10 Oct 2018.

Mad in América Hispanohablante (2017). Radios locas: Redacción Mad in América Hispanohablante. https://madinamerica-hispanohablante.org/radios-locas-redaccion-mad-inamerica-hispanohablante/. Accessed 26 Mar 2019.

Menéndez, C., \& Del Olmo Romero-Nieva, F. (2010). Arteterapia o intervención terapéutica desde el arte en rehabilitación psicosocial. Informaciones Psiquiátricas, 201(3), 367-380.

Pan American Health Organization. (2013). WHO-AIMS: report on mental health systems in Latin America and the Caribbean. https://www.paho.org/hq/dmdocuments/2013/ENGWHOAIMSREG-(For-Web-Apr-2013).pdf. Accessed 10 Oct 2018.

Rebolleda, C., \& Florit, A. (2010). Del concepto de rehabilitación al de recuperación. Informaciones Psiquiátricas. http://www.informacionespsiquiatricas.com/anteriores/201_inf\%20psiq.pdf. Accessed 13 Oct 2018.

Rodríguez, J., Kohn, R., Aguilar-Gaxiola, S. (2009). Epidemiología de los trastornos mentales en América Latina y el Caribe. Pan American Health Organization. http://iris.paho.org/xmlui/ bitstream/handle/123456789/740/9789275316320.pdf. Accessed 14 Oct 2018.

Tchaikovsky, N. (2017). Sistematización de experiencias del Movimiento Ventana, realizadas en el Hospital Psicosocial "José Dolores Fletes Valle" durante el periodo comprendido 2011-2016. Dissertation: Universidad Centroamericana UCA.

Toro, V., \& Terrén, R. (2011). El placer de ser humano. Revista Argentina de Biodanza: una poética del encuentro humano, (1).

United Nations Human Rights. (2018). Human rights violations and abuses in the context of protests in Nicaragua, 18 April-18 August 2018. Office of the United Nations High Commissioner for Human Rights (OHCHR). https://www.ohchr.org/Documents/Countries/NI/ HumanRightsViolationsNicaraguaApr_Aug2018_EN.pdf. Accessed 5 Oct 2018.

United Nations Human Rights. (2019). Seguimiento a la situación de derechos humanos en Nicaragua, Boletín Mensual N.5 - Enero 2019. Office of the United Nations High Commissioner for Human Rights (OHCHR). http://www.oacnudh.org/wp-content/uploads/2019/02/ Nicaragua-Boletin-Mensual-Enero-2019.pdf. Accessed 15 Feb 2019. 
Vallejo, P. (2011). Arte terapia en Trastornos Mentales Severos: efectos terapéuticos derivados de una intervención grupal no directiva, desde el discurso de sus participantes, usuarios de servicios de salud ambulatorios. Dissertation: University of Chile. http://repositorio.uchile.cl/ handle/2250/106322. Accessed 10 Jan 2018.

World Health Organization. (2013). Mental health action plan 2013-2020. The WHO Register. https://apps.who.int/iris/bitstream/handle/10665/89966/9789241506021_eng.pdf;jsessionid= 8A1818837783220915F4E4B0CBA7DB45? sequence=1. Accessed 20 Oct 2018.

Open Access This chapter is licensed under the terms of the Creative Commons AttributionNonCommercial-NoDerivatives 4.0 International License (http://creativecommons.org/licenses/ by-nc-nd/4.0/), which permits any noncommercial use, sharing, distribution and reproduction in any medium or format, as long as you give appropriate credit to the original author(s) and the source, provide a link to the Creative Commons license and indicate if you modified the licensed material. You do not have permission under this license to share adapted material derived from this chapter or parts of it.

The images or other third party material in this chapter are included in the chapter's Creative Commons license, unless indicated otherwise in a credit line to the material. If material is not included in the chapter's Creative Commons license and your intended use is not permitted by statutory regulation or exceeds the permitted use, you will need to obtain permission directly from the copyright holder. 